\title{
Neighbour murders in Rwanda and Poland: what mutilated bodies and killing methods tell us about historical imaginaries and imaginaries of hatred
}

Sidi N'Diaye Institut des Sciences Sociales du Politique

sidi-1@hotmail.fr

\begin{abstract}
This article describes the brutalisation of the bodies of Tutsi and Jewish victims in 1994 and during the Second World War, respectively, and contrasts the procedures adopted by killers to understand what these deadly practices say about the imaginaries at work in Rwanda and Poland. Dealing with the 'infernalisation' of the body, which eventually becomes a form of physical control, this comparative work examines the development of groups and communities of killers in their particular social and historical context. Different sources are used, such as academic works, reports from victims' organisations and non-governmental organisations, books, testimonies and film documentaries.
\end{abstract}

Key words: Rwanda, Poland, massacres, pogrom, imaginaries, torture, myths, neighbours

In order to carry out an exhaustive comparison of murders targeting neighbours, in Rwanda during the 1994 genocide and in Poland during the Second World War, we must reconstruct as far as possible the cruel and inventive methods used by the executioner-neighbours to torture, mutilate and massacre their victims. ${ }^{1}$ Through this examination, we can reveal the nature and depth of inextinguishable imaginaries of hatred and historical imaginaries. If we were to omit such a step, we would evidently miss out on 'the analysis of the said and the unsaid, or the unspeakable, in paroxysms of the past'. ${ }^{2}$ In Rwanda and Poland, Hutus and Poles killer-neighbours would irreversibly inscribe their prejudices, grudges and hatred on their victims, imposing through 'pointless violence' 3 the depths and aggressive marks of their mental structures. Standing as proof is the suffering inflicted on the victims (categories portrayed as irrevocable enemies), the weapons used for their execution and the organisation of the slaughters.

If, through the mutilated bodies and killing methods, the evocation of historical imaginaries and imaginaries of hatred can a priori produce effects of cognitive dissonance, such an evocation finds justification and relevance in the plethora of symmetrical (but also dissymmetrical) links revealed when we analyse and compare the Rwandan and Polish cases. The murders of neighbours in Rwanda 


\section{Sidi N'Diaye}

and Poland ${ }^{4}$ were 'real' occurrences rooted in myths. The strength and vitality of these historical reconstructions helped to form particularly tenacious and harmful imaginaries - that is, imagined notions of the victims. ${ }^{5}$ Moreover, from our point of view, anyone wishing to understand the motivations for the Hutu and Polish brutality towards their Tutsi and Jewish neighbours must necessarily undertake a serious analysis of the treatment of the bodies. This is because, even to understand the 'pragmatic' hypothesis which explains the killers' behaviour in terms of the material benefits of killing or the lure of riches, we must first understand that this 'material interest' was very much a result of the imaginaries that have long associated Tutsis and Jews with wealth and fortune. Among other reasons, it is because they always believed in the myth of Tutsi and Jewish wealth - the myth of the 'Tutsi cow' and the 'Jewish gold' - that the Polish and Hutu neighbours took lives in the hope of becoming rich. Thus, even when the justification for murdering neighbours was based in a supposed 'reality', it always overlapped with imaginaries. These were solid (but not exclusive) explanatory elements for the behaviour of 'ordinary men' who became responsible for extraordinary acts.

A comparison of this phenomenon in Rwanda and Poland rightly brings up another issue: the context in which neighbours were murdered and, for Poland, the role of the Nazi occupiers in the brutalisation and execution of Jewish neighbours by their fellow Polish citizens. We can observe that, in Rwanda, genocide was an unequal confrontation between Hutu killers and their Tutsi victims, which involved no third party. The Hutu neighbours, supported by a murderous regime, acted alone against their Tutsi victims. In Poland, the equation was different. The Nazi occupiers played an essential role in the destruction of the Jews, and this destruction involved various forms of physical participation by Polish citizens. The German soldiers called upon and mobilised Poles to carry out the crime of annihilating the Jews. Although one could legitimately question the comparison of such different situations (Poland between 1939 and 1945 and Rwanda in 1994), these differences have not caused me to radically readjust my reflections, in that the work here focuses only on murders voluntarily committed by neighbours. In fact, it seems that the occupier's presence initially generated an atmosphere of social permissiveness, which made it possible to externalise and publicly assume anti-Jewish hatred (which was already visible in the many pogroms preceding the war). This hatred in turn authorised the 'orgy of murder'6 targeting the Jews.

Based on these observations, ${ }^{7}$ this article will investigate the voluntary brutalisation of Tutsi and Jewish bodies, as well as the procedures that the killers used when ending the lives of their victims. My aim is to find out what these murderous practices tell us about historical imaginaries and imaginaries of hatred in Rwanda and Poland. To this end, this comparative study - which examines the infernalisation ${ }^{8}$ of bodies which ultimately became evidence, including the execution of massacres and the 'formation of cannibal communities"9 - draws on different sources: scientific research, reports from victims' organisations and nongovernmental organisations, testimonies in books and documentary films. 


\section{Brutalised bodies as evidence ${ }^{10}$}

Although the brutalised and infernalised bodies of the victims tell us much 'about the shameful practices'11 of the torturers and killers, they can also serve as evidence, speaking to us from beyond death, attaching an individual/collective responsibility to killing and allowing us to identify the murder weapons. ${ }^{12}$ These bodies reveal elements that not only highlight the psychology and brutal relationship of the killers to their victims (torture, mutilation), but also the operational methods (concrete killing methods) of the killer-neighbours.

\section{Mutilating and torturing bodies}

In a text on acts of cruelty, Véronique Nahoum-Grappe very rightly reminds us that 'in choosing a method of killing, the killer uses a whole style, a whole nonverbal language about their internal utopia'. ${ }^{13}$ Following on from this observation, it is clear that in Rwanda and Poland the ways of killing Tutsis and Jews revealed or can help to reveal the killers' imaginaries and the hatreds that they projected on their victims. In fact, beyond the cold executions (a radical method for a dramatic liberation of the victims: an end to their suffering), what interests researchers is very clearly the torture inflicted on the bodies - that which makes total murder possible, these 'procedures of profanation and degradation' of physical integrity. ${ }^{14}$ Regarding this aspect of neighbour murder, there is clear symmetry between Rwanda and Poland.

We know, thanks to many accounts and studies, that in Rwanda the killerneighbours almost systematically tortured and mutilated their victims before killing them: cutting the Achilles tendon, amputating hands or arms, impaling bodies, cutting off breasts and the rape and genital mutilation of women. So many practices definitively left the mark of a deep-rooted hatred on the bodies of the dead and the escapees. The killers' attention to mutilating many parts of their Tutsi victims' bodies ${ }^{15}$ was in part linked to racist imaginaries and imagery inherited from colonialism regarding the physical differences between Hutu, Twa and Tutsi. For perpetrators, mutilating the bodies was portrayed as a way of wiping out these supposed (and entirely manufactured) physical differences, but also as a means of revenge for the arrogance of Tutsi men and women. It was said that the Tutsis were tall, so the Achilles tendon should be cut to bring them down to the 'normal size'16 of the Hutus. It was said that their noses were fine, so they should be cut off to leave them with none. It was said that Tutsi women were haughty and scorned the Hutus, making it entirely acceptable to rape them and mutilate their genital parts, so that they could never again be desirable or conceive (this will be returned to later on). For example, it was in the name of abolishing these little differences that, on the Mugina hill, the neighbour who killed young Révérien Rurangwa's family disfigured him, first targeting his nose. Révérien Rurangwa describes this as follows:

Sibomana walks towards me with a guffaw: 'Oh, so the eldest Tutsi is sticking his nose outside!' And with a sharp blow, he cleaves my nose from my face. A killer strikes me with a nailed club. He misses my head and shatters my shoulder. I fall to 


\section{Sidi N'Diaye}

the ground. My nose, which is now only hanging on by a scrap of nostril, dangles in front of my mouth. ${ }^{17}$

The killers' obsession with erasing any trace of physical differences (on which they were fixated) of those who, according to them, thought they were superior to the Hutus in part because of their physical characteristics, very often led to dissections. These aimed to confirm the very differences that justified the mutilation of victims' bodies in various places. In telling a story heard from an acquaintance about a young Tutsi girl from Butare, executed by killers who wanted to know what the brain of a Tutsi student looked like, José Kagabo writes:

In front of her parents, they opened the girl's skull, took out her brain, and showed it to them.... Then they killed the parents. First they cut off the wife's feet, and presented them to her husband, saying, 'Smell it! Smell the death'. ${ }^{18}$

Constructing 'problematic' physical differences to serve as aesthetic/physical markers for harming the bodies and identities ${ }^{19}$ of those with whom they were associated, these procedures, 'lasting tortures', ${ }^{20}$ were repeated infinitely on the hills, in the towns and at the killers' barriers and barricades. Moreover, before killing, the killers and killer-neighbours almost systematically made a point of inflicting terrible suffering on their victims, using all kinds of weapons and techniques. The intention behind these pre-execution tortures was obvious: to erase permanently both a presence judged problematic and its memory. It was therefore necessary not only to pretend Tutsis had never existed, but also to ensure that the killing could not be 'that of a human being, even less so that of a relative, but rather that of something evil' that was to be annihilated forever. ${ }^{21}$ The account given by Yvonne Mutimura-Galinier, who was a young girl in 1994 and who a killer decided to 'keep alive to save her for dessert', is particularly enlightening. Her story both tells of the brutal way in which a woman and her child were tortured and massacred by the killers in her neighbourhood and demonstrates this imaginary of hatred evoked above. She says:

They brought in a woman with a child on her back... They struck her and she fell. They lifted her loincloth and started to play with her. They hit her terribly. Blows with a machete, bludgeons, they pushed her legs apart, it was awful.... Then he [one of the killers] lifted his leg. His shoes were like football boots. He brought his foot down on the child [on its head] and the child made a sound. And he was stepping on the child, as if he was stepping on a tyre.... At one point, he stepped on its head again, and I saw something come out of the child's head. And then the child was dead. ${ }^{22}$

Neighbours in Poland used cruelty just as fully as the killer-neighbours in Rwanda. They too loaded their acts with messages of hatred for their victims. In this case, the evocative power of the attacks on Jewish bodies was also particularly clear. Many accounts collected or retold by researchers such as Anna Bikont (Jedwabne, Radzilow, Szczuczyn, Wasosz and other places), Jan Gross (Jedwabne), 
Barbara Engelking (Siemiatycze, Lublin and other places) and Alina Skibinska (Swietokrzyski) $^{23}$ tell of these scenes of torture and mutilation which often preceded the murders of Jews in the Polish countryside. The killers were not happy just to execute the Jews or take them to their deaths: quite the opposite. They systematically humiliated their victims with torture. Szmul Wasserstein, a witness of the Jedwabne pogrom remembers:

They were killing infants at their mother's breast, beating people to death, forcing them to sing and dance. Bloodied and injured, they [the Jews] were pushed into the barn. Then, the barn was doused in petrol and burned. After this, the bandits searched the Jews' houses, looking for the sick and the children. They carried the sick to the barn themselves, and as for the children, they tied several of them together by the legs and carried them on their backs, then put them on forks to throw them into the fire. ${ }^{24}$

Also in Jedwabne, a witness interviewed by Bikont explained that Jews also 'had their throats slit' with knives, were 'drowned' or were 'buried' alive in fields. ${ }^{25} \mathrm{He}$ tells of how he heard 'a dispute between drunken neighbours' during which one answered the other by saying that he had 'jumped a Jewish woman behind the mill' then 'slit her throat'. ${ }^{26}$ Neighbours therefore employed truly sadistic procedures in the extermination of the Jews. In order to inflict suffering and harm, they had to use different torture techniques and show a certain 'shrewdness in cruel one-upmanship'. ${ }^{27}$

Although the killers employed blows, lacerations and bodily mutilations widely in their cruel practices in Rwanda and Poland, the fate they reserved for the bodies of female enemies (girls and women) through rape is particularly worth examining. These rapes had precise meanings, and as Karima Guenivet emphasises, in anthropological reality, the violence inflicted by the rapist not only aims to express his domination over the enemy by seizing power over women, but also to rob them of their identity and exclude them from humanity through humiliating practices' ${ }^{28}$ As documents including the African Rights report specify, in Rwanda many girls and women were raped by their neighbours, very often by men they knew, and in the case of married women, by men that their husbands also knew. ${ }^{29}$ These nearsystematic rapes were major weapons in the hands of these killer-neighbours. For the rapists, sexual possession of the Tutsi girl or woman represented a form of revenge for their supposed arrogance and that of their men. However, more than a form of revenge, rape was almost the expression of a consecration - a triumph over the male enemy, whose mothers, wives and daughters became 'spoils' of war. ${ }^{30}$

The rapes of women reduced to slavery came in addition to other rapes during which the victims' vaginas and genitals were mutilated and tortured. A Human Rights Watch report states that many women suffered individual or collective rape and that very often a variety of objects (sticks, gun barrels, blades, machetes and so forth) were inserted into their vaginas. Moreover, it was not uncommon for the rapists to use boiling water or acid for genital mutilation. ${ }^{31}$

Although to our knowledge Poland did not experience these scenes of mutilation, 


\section{Sidi N'Diaye}

Jewish girls and women were (as in Rwanda) raped by Polish neighbours, then almost systematically killed. Anna Bikont's work includes several accounts about the rape of many victims. These include the account of Awigdor Kochav from Jedwabne. In 1941, he was still a little boy. While hiding, crouched and not moving in a field of wheat, he heard a cry:

'Shut up, dammit,' then a high-pitched sound, something between a shriek and a stifled sob. He realized that a girl was being raped right nearby. ${ }^{32}$

\section{Kochav goes on:}

The pillagers caught us. They took the cart [his father's] and the horse. Our elderly, sick relative, Fejbusz Lejman, was with us. They beat him to death the next day. In the field, we saw them raping the blacksmith Izrael Meir Dymnicki's niece. ${ }^{33}$

Szmul Wasserstein, quoted above, describes a rape scene in his statements:

On Sadowa Road, nearly naked young girls were raped by gangs of thugs. Sara, Sosnowski's daughter, became separated from his son. Five men raped her in the wheat shop. They crushed her smooth, white body. ${ }^{34}$

The account of Stanislaw Zalewski's trial (he was sentenced to death in 1950) also evokes the rape and massacre of Jews:

We brought the Jews out of the cellar ... We took them into the woods, where a trench had been dug ... We took them one by one to the trench and killed them with clubs ... Before killing, five people raped a Jewish woman. After she had been raped, I took Tkacz's club and killed her myself by striking her three times around the head with it. ${ }^{35}$

Rape was therefore a weapon in the hands of neighbours in Poland. In this respect, its symbolism was clearly similar to that of rape in Rwanda. In both countries, what might be called 'genocide-rape', the forceful dishonouring of girls and women in front of their brothers, sisters, husbands, children and parents by people they knew well, was not only intended as a psychological and even physical destruction of the victims. It was also meant to destroy their loved ones, who shared the pain and indelible trauma of one or more members of their family in their own flesh. ${ }^{36}$ For the victim, particularly in Rwanda, this indelible trauma was reinforced by the 'cultural and community proximity' with the executioner. This 'increased the precision and the accuracy of the cruelty which reached the internal space of the victim, whose death alone was not enough'. ${ }^{37}$

\section{Cruelty and its sites}

Cruelty also involves 'reservoirs of crimes', ${ }^{38}$ meaning the sites of death and the places where the bodies were abandoned (roadsides, fields, rivers), thrown ${ }^{39}$ or very 
negligently buried (in collective graves) by the killers. The places where the victims were killed were often also the places where the killers disposed of their bodies. The treatment to which these bodies were subjected post-mortem again reveals a particularly powerful representation of hatred. In his Notes de voyage (Travel Notes), José Kagabo, retelling a story in which a young Tutsi girl told him about her mother, states that she was killed, 'cut into pieces' and 'thrown in the latrines'. Kagabo concludes:

What goes on in the mind of someone who buries a man he knows alive; in the mind of a woman who has slept with a man, had a child with him, and kills that man and that child; in the mind of a man who cuts up his wife? . . I do not claim to know what goes on in the mind of the person who committed the act, but I at least know the meaning of latrines for Rwandans. It means throwing the dead to the worms. They are consciously leaving the victim's flesh to these worms. People who do that know what they are doing. ${ }^{40}$

As Barbara Engelking, Anna Bikont, Jan Gross and others show, in Poland sites such as fields, barns and cemeteries and lakes and rivers in which Jews were drowned were also used as 'dumps' by the killers. On this, Barbara Engelking writes: 'The Polish peasants ... killed with passion, feverishly, with haste and cruelty. . . . They killed in the village, in the fields, in the woods, on the roads. ${ }^{41}$ The victims' bodies were treated with immense contempt and hatred.

\section{Ways of killing: death and its weapons}

The radical elimination of neighbours in Rwanda and Poland used various methods and tools. An examination of bodily harm and injuries provides important information on 'the nature of the weapon used, the brutality of the perpetrator and whether or not the victim resisted'. ${ }^{42}$ Although the murder weapons were not entirely comparable in Poland and Rwanda, in both cases the killer-neighbours mostly used hand-crafted weapons, 'opportunist weapons' ${ }^{43}$ or even (in the words of Wolfgang Sofsky) 'multipurpose objects of civil life'. ${ }^{44}$ In Rwanda, machetes, billhooks, bludgeons, clubs, sticks, knives, lances, hoes, swords and so forth were used to kill, ${ }^{45}$ and in Poland, rakes, forks, sticks, knives, stones and other blunt or sharp objects were used in the same way. To make massacring neighbours possible and effective (particularly in a rural environment), a certain murderous know-how was required. ${ }^{46}$

As clearly shown by the Haglund report on the Kibuye church massacre and the causes of death for the Tutsi victims who took refuge there, hand-crafted weapons (although not the only weapons used by the killers) played a significant role in the massacres. Many pages of the report clearly inventory the injuries inflicted using blunt and sharp objects. ${ }^{47}$ In addition to the Haglund report, which is of inestimable testimonial value, there are statements from survivors of the 1994 genocide. These also tell us about the type of weapons used by the killer-neighbours. One example is the account of Révérien Rurangwa, which describes the ways in which a neighbour, Sibomana, and several Hutu extremists killed his family members on the Mugina hill. He writes: 


\section{Sidi N'Diaye}

Sibomana ... sees my Uncle Jean, who starts standing up, on his left, looks at him, his head back. In one quick movement, the Hutu cuts his throat ... A child screams . . Sibomana shuts him up by hitting him with a machete, which splits his skull. ${ }^{48}$

... I am still conscious enough to see the killers grabbing a woman who is running with a baby on her back. They lie her down and cut off her feet, then her head. As for the baby, a man grabs it, walks over to the cabin where I am hiding, and bursts its head open by throwing it against the brick wall. ${ }^{49}$

The many marks from the injuries left on the victims' bodies by the different instruments of death not only reveal how the killers executed their 'prey', but also give us a reasonably clear picture of the executioners' hatred for the Tutsis, while other testimonies have contributed to making them visible. The words of victims collected by Yolande Mukagasana in Les Blessures $d u$ silence perform this function. Several of these statements emphasise the brutality with which the killers 'worked' (gakura), 'macheted' (gutema) and exterminated (gutsemba) the victims. ${ }^{50}$ Although the killers' hatred for the victims took away their real identities, leaving just a substitute identity (devil, cockroach, traitor and so forth) ${ }^{51}$ which was condemned to disappear, the weapons and killing methods explicitly reveal the structure of these hatreds. Traces of this dimension of the cruelty, represented by the 'weapons and their words', are also found in Poland.

As well as fire, ${ }^{52}$ which was used to burn the Jews alive in Radzilow, Jedwabne and elsewhere, neighbours used different tool-weapons, such as knives, forks, axes, sticks and clubs: ${ }^{53}$ 'The crimes were generally committed with the means available on the farm: with everyday work tools, with objects that were close at hand'. ${ }^{4}$ The executioner-neighbours, in the atmosphere of social permissiveness made possible by hatred and the disturbance of their referential framework, took part in extremely brutal actions and behaviours. As Szmul Wasserstein emphasised at the trial of the Jedwabne killers after the Second World War, 'during the first pogroms, and during the carnage, individuals distinguished themselves by their cruelty' ${ }^{55}$ As the witness statements confirmed, different types of weapons and killing methods were used for this cruelty, on which Anna Bikont brings us highly precise accounts. Asked about Jedwabne, Stanislaw states,

In 1980, I began working for the voivodeship in Lomza, and one of the employees, who had been a teacher in Jedwabne, told me about the bonfire in the barn and the individual murders ... He spoke about Kubrzyniecki, who selected his victims from the Jews who were brought in. A witness told me later that he went into his toilets in the yard and found a Jew there with his throat slit, still alive, gasping... People were being killed in practically every street, in yards. And what happened in the pond? . . When they found Jews, they would drown them. They also drowned them in wells. .. When they found a Yid in a field, they would bury him right there. ${ }^{56}$

Bikont also quotes the transcripts from the trial of Marian Rydzewski, who took part in the pogrom of 5 July 1941 in Wasosz: 
'I went out into the yard, not hurrying,' a witness who had been summoned on the night of the pogrom said, 'and I saw a Yid running away through the field next to our buildings.... There were three men chasing him. There were other people chasing Jews. ... Kozlowski had a bayonet, and the others had murder weapons too, such as large stakes, shovels and forks. ${ }^{57}$

Polish neighbours also used rudimentary but very effective instruments and tools to mutilate and kill their Jewish victims. When they were not buried alive or drowned in lakes and rivers, Jews found death at the hands of executioners using whatever particularly violent methods took their fancy. Again, there are many accounts of this. For example, Anna Bikont reproduces the statement of Halina Zalewska, a Polish woman who told of the murder of a young Jewish woman and her children during the pogrom in Radzilow on 7 July 1941. She says: 'The Jewish woman had her son in her arms. Another was clinging to her legs. Then someone chased the child and hit him with a stick, making his brains spurt out. ${ }^{58}$ Jan Gross quotes similar statements on the murders of Jews in Jedwabne. Before the final scene of the massacre by fire, a radical solution to dispose of all the Jews at once, the Polish neighbours humiliated them by dragging them to different places. Then they inflicted injuries and an atrocious death. The account of a night watchman, Wincenty Gosciki, quoted by Gross, states,

In the morning, as I was going to bed, my wife came and told me to get up, that there was a ruckus. Near our house, people were hitting Jews with bludgeons ... Urbanowski called me and said, 'Look what's happening,' and he showed me the corpses of four Jews ... So I went to hide in my house. . $^{59}$

Clearly, it seems that to found their imagined community ${ }^{60}$ and reestablish a social order thought threatened by the Tutsis and Jews, the killers in Rwanda and Poland decided not to 'simply' kill, but to kill while torturing ${ }^{61}$ the bodies of their victims. In doing so, they also left marks on these bodies, making their imaginaries and their words of hatred extremely visible.

\section{Massacres and the formation of cannibal communities ${ }^{62}$}

In Rwanda and Poland, neighbours killed for different reasons. They killed alone, but they also killed in groups, forming cannibal communities. While individual and collective massacres took on an extreme scale in Rwanda, sometimes neighbours in Poland did not kill in person, shrewdly choosing to hand over the Jews to the local Polish or German authorities in exchange for material rewards. Hatred and imaginaries of hatred thus dictated solitary and shared behaviours that are worth analysing here.

\section{At the heart of the massacres: killing alone}

As emphasised throughout this study, in Rwanda many Hutu neighbours, taken individually, ${ }^{63}$ did not need to be forced into murder or killing for themselves. 


\section{Sidi N'Diaye}

Quite the opposite: they were very willing and active in the massacres. Although the denunciation of Tutsis to the local authorities and armed forces (soldiers, interahamwe $e^{64}$ and so forth) was an important element in the 1994 genocide, this did not stop killer-neighbours from taking the execution of individuals whom they knew well into their own hands, incited among other things by extremist propaganda. Many neighbours coldly (even gladly and lightly) killed other people, including close acquaintances. Although their stories vary as regards their real and multiple motivations, there is no doubt about their direct and constant participation in massacring the Tutsis. Moreover, as time went on, their murderous frenzy grew to increasingly extraordinary proportions. In Une Saison de machettes, Jean Hatzfeld looks at the 'first times' that people killed and at the murderous escalation of the killers in Nyamata. With disconcerting detachment, the executioners recount their initiation into extreme violence and their almost immediate move into routine cruelty and neighbourhood massacres. This is very clear in the statements of Pio and Léopord. Asked about his 'first time', Pio states that 'I had killed chickens, but never an animal the size of a man, like a goat or a cow. The first person, I did it impulsively, without any real thought, even though it was a neighbour. ${ }^{35}$ For his part, Léopord clearly explains:

On the marketplace, I came across a man running towards me ... As he passed, I cut his neck with a machete, across the vulnerable vein. It came naturally to me ... I looked around, there was killing all over the place; I kept chasing others who were fleeing all day. ${ }^{6}$

With their first murders quickly or casually executed, the killer-neighbours gradually acquired a taste for massacre. Consequently, they needed no intermediaries to quench their thirst for blood, killing an immeasurable number of victims. No obligation to follow orders ${ }^{67}$ and no external constraint (aside from a generalised atmosphere of destruction) influenced their minds or their decision. So, very simply, many neighbours, filled with hatred and greed, decided to kill Tutsi neighbours, who had become things or 'disposable' people. ${ }^{68}$ Many killers justified their crimes by pleading that they were in a state of inebriation or that they had received orders from local authorities and leaders. In order to soften the severity of the individual criminal acts that they had carried out, they underplayed their own role, attributing the responsibility for their actions to supposed leaders. In reality, it would be wrong to give any credence to the alibis of these killers, especially as we know what the Tutsis progressively came to represent (enemies to be destroyed) for many extremist Hutus, drunk on racist and murderous words. ${ }^{69}$ Although inebriation may have encouraged them to kill neighbours at certain points, it would be a mistake to see this motive as the main explanation for the massacres and cruelty.

In Poland, the close collaboration with the local authorities, to whom the Polish sometimes 'entrusted' Jews, was an essential way of exterminating the victims (through deportations, massacres and so forth). However, this observation alone leaves us far from the truth. Polish peasants also killed, even if the massacres were not as systematic as in Rwanda. For Barbara Engelking, although it is difficult 
to identify the individual crimes committed by Polish neighbours, particularly because of the lack of sources testifying to them, this does not prove that they never took place. Many crimes were in fact committed, but they were 'more furtive', and as a result 'less likely to come out' ${ }^{70}$ From this observation, it is reasonable to infer that 'solitary' massacres were not only an epiphenomenon in Poland. Polish neighbours, their minds filled with these mythical-historical tales representing Jews as sorcerers, traitors, usurpers, usurers and so forth, killed because they were driven by hatred and because they were tempted by the goods that they thought the Jews owned. Reproducing the notes from the journal of Fela Fisschbein, a young Jewish woman, Barbara Engelking, writes,

Mrs. Hercig, a rich old woman, managed to find refuge by chance with the same peasant as my husband's young brother... The peasant took her off, supposedly to a safer place, and Lord God, he killed her and stole a lot of money. ${ }^{71}$

As stated above, these solitary murders motivated by greed cannot be understood outside of their place in the global structure of the historical imaginaries which long dominated Polish society. Killing a Jew to steal his or her goods: this was very clearly the consequence of an imaginary which has always constructed an image of Jews as privileged and wealthy. For this and/or other reasons, all connected with myths, neighbours repeatedly murdered Jews with the killings sometimes even reaching 'extraordinary' proportions. This is what Barbara Engelking evokes when she tells the story of a peasant from Siemiatycze whose actions, seen by and known to all, went unpunished. She writes,

In Siemiatycze, a peasant also disposed of the seven members of a Jewish family who he had killed in a well. His neighbours knew exactly what he had done: they would say 'it's Treblinka at his place. ${ }^{72}$

Similarly, Jan Gross, reproducing extracts compiled from judiciary archives by Alina Skibinska and Jakub Petelewicz that relate to the murders of Jews in Swietokrzyski, writes,

The accused killed several hundred Jews who were hiding in the countryside in the Swietokrzyski region. The massacres using rifles, axes or wooden stakes ... were accompanied by acts of physical and psychological cruelty to the Jews who had been taken: women raped and people beaten, shoved, insulted and verbally humiliated. The accused were [Polish] peasants, policemen and so on. ${ }^{73}$

A modus operandi of killing Jews without necessarily being swept up in group mentalities that exalted and promoted collective murder was therefore not as rare as we might believe. Although Polish neighbours killed collectively, and although they also often chose to hunt down and capture Jews and then hand them over to the German or Polish authorities in the hope of being rewarded for their efforts (for example, a bag of rice or sugar), ${ }^{74}$ this did not stop them becoming individually 


\section{Sidi N'Diaye}

responsible for crimes committed personally in their communities. Undoubtedly, the herd and group mentalities can explain some of these attitudes and practices by Polish neighbours. However, they do not explain the very solitary dimensions of their murderous behaviour. Although accounts of this are rare, they clearly reveal the presence of such behaviour in Polish villages and other places.

Thus, the murders of Tutsi and Jewish neighbours in Rwanda and Poland, before being collective undertakings to kill, were first of all individual and 'solidarity' undertakings to dispense death or take life. Historical imaginaries and the unfounded and untruthful elements of their imaginaries of the other undoubtedly constitute solid arguments to explain these murders committed by individual Hutu and Polish neighbours in times of extreme violence. In order to sketch out the exhaustive structure of neighbour murder, we now need to look at the collective massacres perpetrated by killer-neighbours in Rwanda and Poland, and within these massacres, explain the formation of cannibal communities or communities of killers.

\section{At the heart of the massacres: killing as a community}

In order to understand the underlying logic for the formation of cannibal communities, it is important to realise that collective massacre requires killers to make a tacit pact that binds them in the long term. This pact is the 'unanimous injunction' described by Alain Corbin in relation to the festive and public execution of a young nobleman in Hautefaye. Everyone 'must take part in the victim's torture. The person who has just struck moves away to make room for another, who after striking, moves away and is immediately replaced.' It is about a union: sealing a blood pact by committing a shared act and proving that you belong to the group by participating in a slaughter which ultimately 'allows the group to bond'. ${ }^{75}$ Based on this observation, we can establish clear similarities and connections for Rwanda and Poland with regard to the formation of communities of killers united by committing acts of cruelty and carrying out massacres. Although in the formation of these communities there are still a few differences between Hutu and Polish neighbours (particularly concerning the effective participation of women and children in the massacres of Tutsis and Jews), these differences do not affect the motives that explain the coming together of individuals around a project of collective murder. ${ }^{76}$

In Rwanda, neighbours formed communities of killers or 'groups of attackers' (ibitero) whose members were often freely recruited. Many neighbours, completely unforced, decided to join these groups, which had become a simple and fast route to material comfort and pseudosocial respectability connected to the possession of usurped goods. A real get-rich-quick strategy based on theft, spoliation and pillaging emerged. This phenomenon, amply described by an African Rights report (among other sources), saw peasants committing body and soul to the destruction of close acquaintances, abolishing moral inhibitions and neighbourhood solidarity in favour of prosaic material interests. ${ }^{77}$ Many peasants benefited substantially from the mass Tutsi massacres. 'Aside from what they could steal, and the cattle they could eat, the most important possession for rural populations was land 78 - that of the victims whom they killed. 
In very exceptional cases, a few reluctant neighbours were forced to join groups of killers. As well as the armed and organised militia, the interahamwe and the impuzamugambi, ${ }^{79}$ all social categories participated in erecting barriers and barricades, hunting down Tutsi neighbours, catching and killing them. Men, women and children all took part in the massacres. According to the African Rights report, the creation of communities of killers, unlike in Poland, followed a precise plan by the Hutu extremist leaders, who were physically involved in the massacres. By inciting the population to murder, they created a Hutu collective identity from scratch, born out of the radical extermination of the Tutsis by a united Hutu people working as one. Even beyond a collective identity, they were creating a nation of individuals who were 'complicit' in carrying out the same, single genocide:

The extremists wanted everyone to be tainted with the blood of those who had died. Then, there could be no going back... . The plan was to divide Rwandese into killers and killed with no middle ground. ${ }^{80}$

The genocide was therefore a way for the killers to recreate or remake a community by ripping the Tutsi category out of the Rwandan social body. ${ }^{81}$ This new community could only emerge after a 'rite of passage, ${ }^{82}$ a process in which men and women had to be sacrificed. At the end of this process, after participants had been put to the test (in the Rwandan case, massacre), the executioners finally acquired the rights to assume their new identity and become a part of their new community. The rite of passage led to the formation of groups of killers, made clear by several statements from members. Examples include the many accounts collected and reproduced by Jean Hatzfeld in Une Saison de machettes. It was not enough for neighbours to join a group of attacker-killers (sometimes managed by interahamwe); they also needed to prove concretely their involvement in the killings and their commitment to the group in exchange for the right to enter the structures that welcomed them. Testifying to this, Léopord, one of the killers interrogated by Hatzfeld, explains,

People who didn't hit right or who pretended to hit would be encouraged. They would be advised on how to do better. They might also be forced to take a Tutsi themselves, in swamps or in front of their houses, and kill him or her in front of the group..$^{83}$

The engagement and integration of Hutu neighbours into several groups of killers was an essential element in the effective hunting down and murder of Tutsi neighbours who had fled and were hiding out in forests or fields. It was no coincidence that the Tutsi genocide very quickly came to be called a 'popular' genocide and a 'neighbourhood' massacre. The massive and continuous presence of the civil populations in the long scene of the massacres (neighbours, but also others) justified the use and promotion of these words. Therefore, the massacre of Tutsi neighbours was essentially also the work of countless 'terrible crowds' of 'ordinary people 84 transformed into bloodthirsty killers by the thrill of following the group. In this 


\section{Sidi N'Diaye}

and other ways, these communities of killers were not so different from the communities of Polish executioners.

In Poland, the killer-neighbours also formed groups to carry out their acts, but these were made up almost exclusively of adult men. Unlike in Rwanda, women and children were not major players in the methods used to kill the Jews. In Radzilow, Jedwabne and Swietokrzyski as well as elsewhere in small Polish towns, it was primarily communities of killers composed of men who attacked the Jews and their possessions. However, as in Rwanda, contrary to the assertions of many killers after the Second World War, Polish neighbours did not always act collectively under pressure from the German or Polish authorities to persecute and exterminate the Jews. As Anna Bikont reminds us, using the statement of a witness to the Jedwabne pogrom, many Polish people in the region acted freely. Stanislas' account makes this very clear:

It is not true that the Polish acted under the surveillance of armed Germans. . . . The Laudanskis (a family of committed killers), among others, did it. The day of the massacre, they went to all the Poles to say: 'Come with us. Either you're with us, or you're against us.' The whole town knew the role they had played in it. ${ }^{85}$

Krystyna Modrzewska, a Polish woman from the Lublin district, whose words are quoted by Barbara Engelking, is even more explicit in her account:

In order to hunt down the groups of Jews, a rural volunteer militia had been set up. In all the hamlets in our community and all the communities of the Lublin district, lots of young people readily joined these militias. They were given weapons, of course, but against the Jews, wasn't a sturdy stick enough? So the men of the countryside patrolled with their clubs and hunted the Jews. ${ }^{86}$

As well as the voluntary commitment of Polish peasants who, it seems, saw 'few objections to participating' in hunts and other violence against Jews, ${ }^{87}$ the statements of victims, witnesses and participants in the hunts give us a clear picture of the systematic way in which the leaders recruited neighbours. ${ }^{88}$ As in Rwanda, both personal choices to join groups of killers and mobilisations provoked by intermediaries (rarely by force) contributed to the formation and effectiveness of cannibal communities. On a more or less freely organised basis, many neighbours scoured the streets, forests and fields and searched houses for Jews. Anti-Jewish pogroms were organised in an equally free manner. To be sure that no Jew would escape, the Polish neighbours checked every corner of the villages and their surroundings, sometimes even with the involvement of women and children. The effectiveness of these tracking and hunting procedures made possible the methodical and particularly brutal massacre of Jewish neighbours, who were caught in an open-air prison. Unhindered and with nobody attempting to stop them, the cannibal communities were able to do as they liked, unpunished. This would also be the case in Rwanda, almost half a century after the Jewish genocide in Europe.

We can thus see many symmetries between killings of neighbours in Rwanda 
and Poland. The killers' justifications for these acts had their roots in the reactivation of negative myths and imaginaries, in tales that reproduced a plethora of fantasies, in base economic considerations and, in short, structures of imaginaries and systems of belief struck by 'irrational rationalities'. Ultimately, therefore, attempting to explain imaginaries (of history and of hatred) and their structures through the observation of brutalised Tutsi and Jewish bodies is of great interest to researchers. Although decoding the discourse of social actors is an effective way of accessing their imaginaries and the meanings of these, analysing the procedures for the profanation of victims' bodies and their execution is just as useful in understanding these imaginaries. Consequently, as this study shows, working to render the possible points of convergence between the imaginaries of the killer-neighbours in Rwanda and Poland, as well as the ways in which these were concretely expressed, is not a vain endeavour.

\section{Notes}

1 Translated from the author's French by Cadenza Academic Translations.

2 A. Corbin, 'Douleurs, souffrances et misère du corps', in A. Corbin, J.-J. Courtine \& G. Vigarello (eds), Histoire du corps: tome 2, de la révolution à la Grande Guerre (Paris, Seuil, 2005), p. 226.

3 P. Levi, Les naufragés et les rescapés: quarante ans après Auschwitz (Paris, Gallimard, 1989), p. 104.

4 For Rwanda, it is interesting to read J.-P. Chrétien (ed.), Rwanda: Les médias du génocide (Paris, Karthala, 1995); and J.-P. Chrétien \& M. Kabanda, Rwanda, racisme et génocide: l'Idéologie hamitique (Paris, Belin, 2013); for Poland, useful reading includes the recent work of Joanna Tokarska-Bakir, Légendes du sang: pour une anthropologie de l'antisémitisme chrétien (Paris, Albin Michel, 2015); see also A. Cala, The Image of the Jew in Polish Folk Culture (Jerusalem, Magnes Press, 1995).

5 As we will see, and as Barbara Engelking reminds us, these murders inflicted on neighbours concerned many Polish villages. See B. Engelking, On ne veut rien vous prendre... seulement la vie: des Juifs cachés dans les campagnes polonaises 1942-1945 (Paris, Calmann-Lévy, 2015).

6 J. Grabowski, Hunt for the Jews: Betrayal and Murder in German-Occupied Poland (Bloomington, Indiana University Press, 2013), p. 54. In the case of Poland, the work here does not focus on the central dimension of the genocide (imprisonment of Jews, liquidation of ghettos from 1942 and elimination in gas chambers). The local populations played more than a minimal role. This allows us to understand the kind of environment faced by Jewish fugitives seeking aid. There were an estimated 250,000 of these Jews in hiding. Jan Grabowski reminds us of just this: 'Historians agree today that close to 10 percent of the 2.5 million Polish Jews who survived until the summer of 1942 tried to escape extermination.' See Grabowski, Hunt for the Jews, p. 2.

7 These observations are themselves part of a project on neighbour murder in Rwanda and Poland that I have been working on for over two years. Several 


\section{Sidi N'Diaye}

exchanges with researchers and victims whom I met in Kigali informed me about the bodies and how they were treated.

8 D. Crouzet, 'Imaginaire du corps et violence aux temps des troubles de religion', in J. Céard, M.-M. Fontaine \& J.-C. Margolin, Le Corps à la renaissance (Paris, Aux Amateurs du livres, 1990), pp. 16-27.

9 I will look later at this wording taken (and translated) from Corbin, 'Douleurs, souffrances et misères du corps'.

10 F. Chauvaud, Les Experts du crime (Paris, Aubier, 2000), p. 8.

11 F. Chauvaud (ed.), Corps saccagés: une histoire des violences corporelles du siècle des Lumières à nos jours (Rennes, Presses Universitaires de Rennes, 2009), p. 22. On this matter, it is also worth reading É. Anstett \& J.-M. Dreyfus (eds), Cadavres impensables, cadavres impensés: approches méthodologiques du traitement des corps dans les violences de masse et les génocides (Paris, Pétra, 2012).

12 Also worth reading on this is C. Koff, La Mémoire des os (Paris, Hélö̈se d'Ormesson, 2005).

13 V. Nahoum-Grappe, 'Ex-Yougoslavie: la haine ethnique et ses moyens: les viols systématiques', Confluences 17 (1996), 37-54, 44.

14 Corbin, 'Douleurs, souffrance et misère du corps', 21.

15 This attention to precise body parts, as Stéphane Audoin-Rouzeau explains, almost always tells us the executioner's intention. The mutilation of these areas was therefore a highly meaningful act. For more information, see chapter 4 of Combattre: une anthropologie historique de la guerre moderne (XIX ${ }^{\mathrm{e}}-X X I^{\mathrm{e}}$ siècle) (Paris, Seuil, 2008). Also worth reading is Frédéric Baillette's article, 'Figures du corps, ethnicité et génocide au Rwanda', Quasimodo, 6 (2000), 7-38.

16 P. Gourevitch, Nous avons le plaisir de vous informer que demain nous serons tués avec notre famille (Paris, Denoël, 1999), p. 230. Gourevitch observes that cutting the Achilles tendons, along with amputating hands and arms, 'was one of the preferred methods of torturing the Tutsis during the genocide'.

17 R. Rurangwa, Génocidé (Paris, Presses de la Renaissance, 2006), pp. 69-70.

18 J. Kagabo, 'Après le genocide: notes de voyage: Août 1994', Les Temps modernes, 583 (1995), 102-25, 111.

19 'Identities', because bodily mutilations are also an attempt to erase the victim's ethnic group of origin.

20 To use the words employed by Wolfgang Sofsky in Traité de la violence (Paris, Gallimard, 1998), p. 80.

21 Corbin, 'Douleurs, souffrance et misère du corps', 21.

22 Extract from the documentary film by Mehdi Bâ and Jeremy Frey, 7 jours à Kigali. La Semaine où le Rwanda a basculé (Paris, Java-Films, 2014), 60 min.

23 A. Bikont, Le crime et le silence: Jedwabne 1941, la mémoire d'un pogrom dans la Pologne d'aujourd'hui (Paris, Denoël, 2011); J. Gross, Les Voisins: 10 juin, un massacre de Juifs en Pologne (Paris, Fayard, 2002); Engelking, On ne veut rien vous prendre; A. Skibinska, 'Perpetrator's self-portrait: the accused village administrators, commune heads, fire chiefs, forest rangers, and gamekeepers', East European Politics \& Societies, 25 (2011), 457-85. 
24 Bikont, Le crime et le silence, pp. 17-18.

25 Ibid., pp. 95-6, 175-6.

26 Ibid., p. 95.

27 V. Nahoum-Grappe, 'L'Usage politique de la cruauté: l'épuration ethnique (ex-Yougoslavie, 1991-1995)', in F. Héritier, De la violence (Paris, Odile Jacob, 1996), p. 228.

28 K. Guenivet, 'Femmes, les nouveaux champs de bataille', Quasimodo, 9 (2006), 197-213, 198.

29 African Rights, Rwanda: Death, Despair and Defiance (London, African Rights, 1994), pp. 411-23, 749. It is estimated that over 250,000 Tutsi women were raped in 1994.

30 African Rights, Rwanda: Death, Despair and Defiance, p. 750; see also the report by AVEGA-Agahozo, Survey on Violence against Women in Rwanda (Kigali, AVEGA, 1999).

31 Human Rights Watch, Shattered Lives: Sexual Violence during the Rwandan Genocide and its Aftermath (New York, Human Rights Watch Africa, 1996), pp. 2-54.

32 Bikont, Le crime et le silence, p. 264.

33 Ibid., p. 269.

34 Ibid., p. 361.

35 Ibid., p. 388.

36 As well as public rape, in Rwanda the killers very often pillaged their victims' possessions before their eyes. This was not systematic in Poland.

37 Nahoum-Grappe, 'Ex-Yougoslavie: la haine ethnique', 39-44.

38 In the words of Elisabeth Claverie. See her article, entitled 'Ménager la victime? Ménager le coupable? Jugement, révision et histoire devant le Tribunal pénal pour l'ex-Yougoslavie', Droits et Cultures, 58 (2009), 141-59.

39 In Rwanda, when the bodies were not thrown into the latrines (among other places), they were abandoned on the roads to the mercy of wild dogs.

40 Kagabo, 'Après le génocide', 121-3; on the same subject, useful reading includes African Rights, Rwanda: Death, Despair and Defiance, pp. 342-3.

41 Engelking, On ne veut rien vous prendre, p. 246.

42 M. Daniel, 'Le Repérage des traces et des signes de violence sur le corps meurtri au XIX ${ }^{\mathrm{e}}$ siècle (l'exemple du département de la Seine-Inférieure)', in F. Chauvaud (dir.), Corps saccagés: Une histoire des violences corporelles du siècle des Lumières à nos jours (Pur, 2009), p. 45.

43 H. Dumas, 'Juger le génocide sur les collines: une étude des procès gacaca au Rwanda', doctoral thesis, EHESS, 2013, p. 471.

44 Sofsky, Traité de la violence, p. 31.

45 On murder weapons in Rwanda, useful reading includes the report by IBUKA, Commission for the Memorial of Genocidal Massacres in Rwanda, Arme de la mort préfecture de Kibuye (Kigali, n.p., 1996).

46 See, for example, Dumas, 'Juger le génocide sur les collines'; Kagabo, 'Notes de voyage Août 1994'.

47 For more details, see W. Haglund \& Physicians for Human Rights, Investigations 


\section{Sidi N'Diaye}

at Kibuye Roman Catholic Church: Kibuye, Rwanda, vol. 2 (Boston, Physicians for Human Rights, 1997).

48 Rurangwa, Génocidé, pp. 54-5.

49 Ibid., pp. 66-7.

50 Y. Mukagasana, Les blessures du silence: témoignages du génocide (Paris, Actes Sud, 2001), pp. 24-9.

51 Elsewhere, Alain Corbin explains that the essential key to understanding 'the enigma is not to consider the real victim, but the identity and the meaning given to them by the community'. See A. Corbin, Le Village des cannibales (Paris, Aubier, 1990), p. 119.

52 In Rwanda, the killers also used fire. This is described in the African Rights report cited above, in a section entitled 'Burning People Alive' (p. 341-6). Famous RTLM presenters Valérie Bemeriki and Habimana Kantano explicitly confirmed the use of fire by the killers: 'Our country is ridden with cockroaches. Catch them and make them suffer ... With the help of the government army, the inhabitants of the Rugenge neighbourhood have set fire to the cockroaches, they have set fire to them, they'll wish they had never been born. As I speak to you, they're burning there, they are catching fire right now.' This is taken from the film 7 jours à Kigali..

53 See Bikont, Le crime et le silence, pp. 17-18.

54 Engelking, On ne veut rien vous prendre, p. 247.

55 Bikont, Le crime et le silence, pp. 22-3.

56 Ibid., p. 175.

57 Ibid., p. 388.

58 Ibid., p. 402.

59 Gross, Les voisins, p. 116.

60 B. Anderson, L'Imaginaire national: réflexion sur l'origine et l'essor du nationalisme (Paris, La Découverte, 2006).

61 A slight adaptation of the words of Maurice Godelier and Michel Panoff, Le Corps humain: conçu, supplicié, possédé, cannibalisé (Paris, CNRS, 1999), p. 13.

62 Alain Corbin uses the term 'cannibal people' to refer to these killers with a thirst for pain, terror and blood: 'Douleurs, souffrances et misères du corps', 230. I also use these words to designate groups of killers, and it is not therefore a reference to eating human flesh.

63 On this point, Charles Mironko reminds us that none of the killers questioned during his investigations admitted killing outside of a group. However, he rightly points out that we should not dismiss the possibility that the killers used a 'discursive strategy' to dissipate their individual responsibility. In fact, like Mironko, I believe that it is important not to see groups of killers exclusively as a monolithic bloc. Individuals, social actors, took on the responsibility of killing. They did not abstain or shy away from it as others did, sometimes risking their lives. Although it is difficult to determine the precise individual responsibility of the executioners in killing their neighbours, this should not stop us from taking an interest in their personal behaviour and subjectivity. From this point of view, it is not possible to back the conclusions of Ann Lee Fujii, who (among others) believes that the act of killing can only be analysed in terms of collective participation. 
For further details on Mironko, see 'Ibitero: means and motive in the Rwandan genocide', McMillan Center for Genocide Studies, 23 (2006), 189-90; and A. L. Fujii, Killing Neighbors. Webs of Violence in Rwanda (Ithaca, Cornell University Press, 2009), p. 171.

64 Literally, 'those who stand together'. The interahamwe were the armed wing of the party-state, the MRND, before and during the genocide. The National Revolutionary Movement for Development, renamed the National Republican Movement for Development and Democracy in 1991, was founded by President Juvénal Habyarimana following a coup d'état in 1974. It was dissolved in 1994.

65 Hatzfeld, Une saison de machettes (Paris, Seuil, 2003), p. 28.

66 Ibid., p. 31.

67 Evidently, the same does not apply in all cases. Some neighbours, as many studies have shown, killed under duress.

68 B. Ogilvie, L'Homme jetable: essai sur l'exterminisme et la violence extrême (Paris, Amsterdam, 2012).

69 This hostility was also connected to what Hélène Dumas has called a 'warrior imaginary' that associated the Tutsis in Rwanda (internal accomplices) with external Tutsi fighters from the Rwandan Patriotic Front (FPR) who were engaged in a war against the Kigali regime. Those nicknamed the inyenzi-inkotanyi (cockroach-fighters) by propaganda ended up becoming the main figure of the threat for Hutu extremists. Many accounts tell of the terrifying imaginaries of the FPR fighter. On this, see Dumas, 'Juger le génocide sur les collines', 388.

70 Engelking, On ne veut rien vous prendre, p. 216.

71 Ibid., p. 217.

72 Ibid., p. 218.

73 J. Gross, Moisson d'or: le pillage des biens juifs (Paris, Calmann-Lévy, 2014), pp. 79-80.

74 Skibinska, 'Perpetrator's self-portrait'.

75 Corbin, Le village des cannibals, pp. 91-118.

76 With regards to the direct participation of women and children in the massacres (act of killing) during the war, in Poland (unlike in Rwanda), I can only find very rare cases of murders committed by young adolescents. Women and children above all participated by assisting the killers, particularly by blocking escape routes for those attempting to flee. On this, see Bikont, Le crime et le silence, p. 407; see also A. Skibinska \& J. Petelewicz, 'The participation of Poles in crimes against Jews in the Świętokrzyskie region', Yad Vashem Studies, 35 (2007), 1-44.

77 The power to kill is also one of the benefits that groups of killers gain from their behaviour. Killing within a group, with the feeling it brings of total impunity, reinforces the killers' 'illusion of being all powerful'. Authorised by moral and referential frameworks that have been turned upside down, they benefit from the suffering of the humiliated victim, ready to be sacrificed after prolonged torture. On this, see (among other works) Sofsky, Traité de la violence, p. 176.

78 African Rights, Rwanda: Death, Despair and Defiance, p. 582.

79 Literally, 'those with a common goal'. The impuzamugambi were the armed wing of the Coalition for the Defence of the Republic (CDR), a Hutu extremist party 


\section{Sidi N'Diaye}

founded in 1992 and dissolved in 1994. On the history of the interahamwe and the impuzamugambi, see, for example, African Rights, Rwanda: Death, Despair and Defiance.

80 African Rights, Rwanda: Death, Despair and Defiance, p. 993; for similar interpretations, see also Mironko, 'Ibitero: means and motive in Rwandan genocide', 188-9; and Fujii, Killing Neighbors, p. 175.

81 This is also suggested by Philip Gourevitch in Nous avons le plaisir de vous informer que demain nous serons tués avec nos familles.

82 African Rights, Rwanda: Death, Despair and Defiance, p. 993.

83 Hatzfeld, Une saison de machettes, p. 43.

84 Corbin, 'Douleurs, souffrances et misère du corps', 217.

85 Bikont, Le crime et le silence, p. 175.

86 Engelking, On ne veut rien vous prendre, p. 142.

87 Ibid., pp. 142-3.

88 Nevertheless, we should remember that groups of killers would sometimes be set up by German and Polish policeman who organised hunts in the woods. Barbara Engelking, among others, shows this very clearly in her work. 